\title{
Patterns of variation in existential constructions ${ }^{*}$
}

\author{
Silvio Cruschina \\ University of Vienna \\ silvio.cruschina@univie.ac.at
}

Received: 08-06-2014

Accepted: 21-11-2014

\begin{abstract}
The main goal of the present paper is twofold: on the one hand, to highlight the patterns of variation among the existential constructions found in Italo-Romance; on the other, to examine the observed microvariation in a comparative perspective in order to identify common properties and general tendencies. Starting from a description of the variation concerning the primary components of existentials, I demonstrate that, irrespective of the superficial morphosyntactic variation attested, all Italo-Romance existential constructions share a fundamental property: their distinguishing features can all be viewed as the reflection of the persistence of formal properties continuing or overlapping with a source construction. This construction is either the locative predication, when be is selected, or the possessive structure, when the existential copula is have. The pivot of the existential construction therefore shows typical properties of arguments, but is however subject to a high degree of instability and variation because it has been semantically reanalysed as the predicate of an abstract contextual domain serving as the argument of the existential proposition. This mismatch between the syntactic and the semantic characteristics of existential structures contributes to the microvariation encountered.
\end{abstract}

Keywords: existential construction; locative; possessive; Italo-Romance; Sardinian.

\section{Table of Contents}

1. Introduction

2. Patterns of variation in Romance

3. Be-existentials in Italo-Romance

4. Have-existentials in Italo-

Romance
5. Alternations in Sardinian

6. Conclusions References 


\section{Introduction}

Over recent decades researches working on existential sentences have revealed and emphasized the special interpretive and structural properties of this construction, offering a fertile territory in which to test syntactic, semantic, and pragmatics theories. Investigations into the semantics of the predication and the pivot (i.e. the nominal phrase featuring in this construction), the Definiteness Effect, the morphosyntactic relationship between its components, as well as the properties concerning its information structure and pragmatic function, have not only shed light on significant aspects of this construction, but have equally made a remarkably influential contribution to a variety of issues in general linguistic theory (cf. McNally 2011 for an overview). In particular, even though they share certain general characteristics, existential sentences vary noticeably from language to language in both structural and semantic properties, providing interesting and challenging data on parametric variation. To cite just one simple example, it has been noted that whereas languages like English and Spanish are subject to a socalled Definiteness Effect, which limits the ability of definite and quantificational pivots to appear in the construction, languages such as Italian and Catalan do not seem to be sensitive to such a restriction (examples from Leonetti 2008a: 132-134; see also McNally 1992, Moro 1997): ${ }^{1}$

(1) a. There are some / two / many / few / no / Ø $\}$ dogs.

b. * There is $\{$ it / the $\operatorname{dog} /$ that $\operatorname{dog} /$ Fido $\}$.

(2) a. Hay $\{$ algunos / dos / muchos $/$ pocos $/ \varnothing\}$ perros. has-PF \{some / two / many / few / Ø $\}$ dogs

b. *Hay $\{$ el / el perro / ese perro / Fido $\}$. has-PF $\{$ it / the $\operatorname{dog} /$ that $\operatorname{dog} /$ Fido $\}$

This paper draws from a large set of data collected in the field as part of the project 'Existential constructions: An investigation into the Italo-Romance dialects', University of Manchester, funded by the Arts \& Humanities Research Council (grant AH/H032509/1) and directed by Delia Bentley (from October 2010 to December 2013). Part of the data and observations presented here have already been discussed or will appear in other publications by the project members (Bentley 2010, 2011, 2013, Ciconte 2011, 2013, Cruschina 2012, 2014, Bentley, Ciconte and Cruschina 2013a,b, in press, Bentley and Ciconte forthcoming, Bentley and Cruschina forthcoming). I am indebted to Delia Bentley for useful comments on this article; I also thank two anonymous reviewers for their suggestions and remarks

1 Exceptions to the Definiteness Effect in English are numerous and have been widely described in the literature (cf. Milsark 1974, Rando and Napoli 1978, McNally 1992, Abbott 1993, 1997, Ward and Birner 1995). Despite these exceptions and their motivations, the contrast between English, on the one hand, and Catalan and Italian, on the other, with respect to the types of pivot admitted in existentials remains evident. Whether in the latter languages the constructions with definite pivots are genuine existentials or in fact locative structures in disguise is further complication to the issue and to the crosslinguistic comparison (cf. Leonetti 2008a, Cruschina 2012, Villalba 2013). 
(3) a. C'è uncane / C'è il cane / C'è Gianni.

(Italian) PF-is a dog / PF-is the dog / PF-is John

b. Hi ha un gos / Hi ha el gos / Hi ha en Joan. (Catalan) $\mathrm{PF}$ has a $\operatorname{dog} / \mathrm{PF}$ has the $\operatorname{dog} / \mathrm{PF}$ has the John

From a purely formal viewpoint, the only obligatory component of the existential construction is the pivot, namely, the DP denoting the entity or the individual about which the existential proposition expresses existence or presence in a context (Francez 2007, McNally 2011: 1830). Other elements may be present or are structurally required depending on the specific language, and this variation further contributes to the number of crosslinguistic differences. A copula is generally necessary, but is not needed in all languages or in all contexts. Similarly, an additional phrase, i.e. the 'coda' (for example a locative phrase), is also commonly found in existentials, but its presence is not requested in all circumstances. Some languages, including several Romance varieties, also exhibit a locative pronominal form, to which I will refer as proform (abbreviated as PF in the glosses). For structural reasons, some languages also require an expletive element in subject position (EXP), which may coincide with the proform as in English. The composition of the existential construction in English and across Romance can be observed in the following preliminary set of examples (Bentley, Ciconte and Cruschina 2013a):

(4) (Expletive) (proform) (copula) pivot (coda)

$\begin{array}{llll}\text { (5) a. There are } & \text { some books } & \text { on the table. } \\ \text { EXP/PF } & \text { COPULA } & \text { PIVOT } & \text { CODA }\end{array}$

(English)

b. $\mathrm{Ci}$ sono dei libri sul tavolo. (Italian) PF be.3PL some books on-the table

c. Il y a des livres sur la table.

(French) EXP PF have.3SG some books on the table $\begin{array}{lllll}\text { d. Hay } & \text { unos libros sobre la mesa. } \\ \text { have.3SG-PF } & \text { some books on the table }\end{array}$

(Spanish)

$\begin{array}{llll}\text { e. Sunt nişte cărți } & \text { pe masă. } \\ \text { be.3PL } & \text { some books } & \text { on table }\end{array}$

(Romanian)

The main goal of the present paper is, on the one hand, to highlight the patterns of variation among the existential constructions found in Italo-Romance, including Sardinian; ${ }^{2}$ on the other, to examine the observed variation in a comparative perspective in order to identify common properties and general tendencies. More specifically, I will focus on one aspect of existentials which may offer new insights into parametric variation, among other things: copula selection. There is crosslinguistic variation concerning the choice of the verbal copula used to express existential propositions, but most languages -though in fact not all-

2 The inclusion of Sardinian into the Italo-Romance group is actually debated. This classification issue, however, will not be discussed in this paper (see Jones 1988, Posner 1996, a.o). 
employ either have or be as copula of the existential construction. ${ }^{3}$ A number of further structural differences seem to depend on this choice, so that, according to the type of copula and the associated features, existentials come to resemble either locative or possessive structures. The similarities between the linguistic indication of the existence or presence of some entity and the expression of a locative or possessive relation have long been recognized (cf. Lyons 1967, Clark 1978, Freeze 1992, Heine 1997, Koch 2012, a.o.), to the extent that it has even been claimed that these constructions are all syntactically related and derived from a common underlying structure (see, e.g., Freeze 1992, 2001). It would be natural, however, to assume that all existential constructions share the same semantics, and that the differences related to the selected copula are purely formal. Evidence of this kind is the source for the Benveniste/Kayne generalization (Benveniste 1966, Kayne 1993), formulated especially in reference to possessive and auxiliary structures, where a similar choice is also found. According to this generalization, have is analysed as the combination of the light or semantically empty copula be and a preposition (cf. also Szabolcsi 1983, Freeze 1992, Uriagereka 1998, a.o.). ${ }^{4}$

Starting from a description of the variation concerning the primary components of existentials and related to the copula used in the Italo-Romance, in this paper I demonstrate that, irrespective of the superficial morphosyntactic variation attested, all Italo-Romance existential types share a fundamental property: their distinguishing features can be viewed as the reflection of the persistence of formal properties continuing or overlapping with a source construction. This construction is either the locative predication, when be is selected, or the possessive construction, when the existential copula is have. ${ }^{5}$ Despite the fact that the meaning has moved forward to express existentiality, the morphosyntactic properties of the existential construction have remained inert or resilient to change. The high degree of variation registered by the Romance existential constructions may therefore be partially explained with reference to these residual features from the source construction. The next section will present a concise overview of the patterns of variation found in Romance $(\S 2)$, but the scope of the paper will then narrow down to data from Italo-Romance ( $(3-4)$ and Sardinian ( $(5)$. Even though the main goal

3 The use of copulas etymologically derived from verbs roughly equivalent to English stay and hold will be discussed below (cf. $\S \S 2-3$ ). German resort to the verb give in its existential sentences, which in some analyses is considered an extension or a development from have (Czinglar 2002, Lenz 2007a,b). The argument that existentials derive from or are parallel to a locative or possessive source construction holds not only for Romance, but also for other languages (cf. Heine 1997, Creissels 2013 and Lutz 2013, a.o.). It must be clear that in this paper I do not use the expression 'source construction' strictly in a diachronic sense, and that I remain agnostic as to whether the similarity between existentials and locatives or possessives is a matter of linguistic change or simply synchronic overlapping. In what follows, and especially in section 4.2, I will adopt a descriptive model of language change and grammaticalization, but, in fact, a thorough diachronic study would be necessary to determine the actual relationship between existentials and their source constructions. Also, the term 'source' should not been understood in its locative sense.

Several scholars describe the meaning of copula be and possessive have as existential. Here, I use the term 'existential' exclusively to refer to the specific morphosyntactic construction in (4). 
of this paper is descriptive, in section $4.2 \mathrm{I}$ will examine the argument and predicative structure of the constructions under investigation and will suggest a preliminary analysis of their formal similarities and differences.

Ever since the pioneering work by Paola Benincà in the late eighties and early nineties (cf., e.g., Benincà 1994), Italo-Romance dialects have represented a fertile field of research and a rich mine for the formal linguists working within the generative framework and particularly interested in dialectal variation. As is well known, the degree of microvariation found in Italian dialects is very high, and existential constructions are not an exception in this regard (cf. Bentley 2013, Bentley, Ciconte, and Cruschina 2013b, in press, Bentley and Ciconte forthcoming, Bentley and Cruschina forthcoming; cf. also Manzini and Savoia 2005). To describe the parametric variation related to existential structures, therefore, one need not refer to typologically distant languages; crosslinguistic differences within the Romance family, and in particular within Italo-Romance varieties, offer sufficiently comprehensive and convincing empirical data demonstrating that, morphosyntactically, existential constructions can be subdivided into two major types: those which share similarities with locatives, and those which display features in common with possessives. These dialects often diverge minimally in significant and interesting ways with respect to minor properties which the linguist can isolate in order to observe what lies behind surface differences and what changes in otherwise highly homogenized grammars. If it is undoubtedly true that "the study of differences among languages must obviously proceed in tandem with the study of what they have in common, that is, with the study of the principles of Universal Grammar (UG) that interact with language-specific parameters to yield observed variation" (Kayne 2000: 3), I also concur with Kayne that such microvariation provides the linguist with the tools proper of a language laboratory, where it is possible to determine which phenomena are correlated with particular parametric options and how such relationships are mapped on to the syntax.

\section{Patterns of variation in Romance}

Romance existentials exhibit an obligatory copula, which is the outcome of one of the following Latin verbs: ESSE, HABERE, STARE or TENERE. ${ }^{6}$ The existential copula is ESSE in Romanian (6a), Italian, Corsican, Friulian, Romansh, Ladin (6b), most Campidanese Sardinian varieties, as well as northern, central and southern Italo-Romance dialects (6c). This copula is also found in Nuorese and Logudorese Sardinian dialects, although limited to definite DPs (cf. § 5).

(6) a. Sunt şi profesori buni. are also teachers good

(Romanian)

'There are also good teachers.' (Cornilescu 2009: 218)

The existential copula of classical Latin is ESSE, but existentials with HABERE are found in late Latin with a nominative or accusative pivot (Cennamo 2011). In some early Italo-Romance vernacular texts, moreover, existential constructions similar to locatives and possessives are simultaneously attested (Ciconte 2010). 
b. L èa tanta zente. EXP was many people

(Ampezzan, Ladin)

'There were so many people.' (Haiman and Benincà 1992: 168)

c. Ci sunnu carusi ca jocanu nt'a chiazza ranni. (Sicilian) PF be.3PL children who play.3PL in the square big

'There are children playing in the main square.'

Copula HABERE is employed in Spanish, Asturian (7a), Galician, European Portuguese, French, Logudorese and Nuorese Sardinian. The copula HABERE is also found in Catalan (7b), ${ }^{7}$ and in some Salentino and Calabrian dialects. Copula STARE is typical of some central and upper southern Italo-Romance dialects (7c):
a. Nun hai nengún motive pa tantu xaréu. not has-PF any reason for such racket 'There's no reason for such a racket.'
b. A la reunió hi havia el president. at the meeting $\mathrm{PF}$ had.3SG the president
(Asturian) 'The president was at the meeting.' (Rigau 1997, 396)
c. Cə sta n'ommə forə a porta. $\mathrm{PF}$ stay.3SG a man outside the door
(Quarto, Naples)
'There's a man by the door.'

The choice of the copula, in turn, can be concomitant with the lack or presence of number agreement with the postcopular pivot, as well as with the presence or absence of a proform. The latter, in particular, is an innovation of Romance that is absent in Latin. Interestingly, in those Romance varieties which exhibit a proform (cf. (1c) and (2b-c) above), this is morphologically identical to the locative clitic, suggesting that it derived historically from a locative adverb. ${ }^{8}$ On the other side, a proform is missing in Romanian (6a), Ladin (6b), Friulian (8a), Romansh, some Venetan dialects (in the provinces of Treviso and Belluno), a number of southern and extreme southern Italo-Romance dialects (8b-c), European and Brazilian Portuguese (8d):

$$
\begin{array}{lllll}
\text { a. } & \text { A } & \text { 'soy } & \text { dai } & \text { 'fru:s. } \\
\text { SBJ.CL } & \text { be.3PL } & \text { some } & \text { children }
\end{array}
$$

(Friulian)

'There are some children.' (Manzini and Savoia 2005: III, 42)

b. Stè na chəcèjnə jind' a tuttə i casərə. (Polignano, Puglia) stay.3SG a kitchen in to all the houses

'There is a kitchen in every house.'

$7 \quad$ See Rigau (1997) for the different behaviour of Algherese, the Catalan dialect spoken in Alghero (Sardinia), which exhibits a pattern similar to the Sardinian dialects (cf. § 5).

For the etymological sources of the proforms in modern Romance, see Badía Margarit (1951: 266), Wagner (1960: 624), Rohlfs (1969: 899), Maiden (1995: 167), Blasco Ferrer (2003), Benincà (2007). 

c. Intru a sta frutta ave tanti samenti. (Soleto, Salento) in to this fruit have.3SG many seeds
'In this fruit there are many seeds.'
d. Tem duas soluçoes para esse problema. (Brazilian Portuguese) have.3SG two solutions for this problem
'There are two solutions for this problem.'

In Spanish, Galician, and Asturian, a lexicalized proform solely appears on the present tense of the existential copula HABERE. This can be observed by comparing the example in (9a), with present tense $h a-y$, lit. have.3SG-PF (cf. also (7a) above), with (9b), in the past tense:
a. Non hay
ningún problema.
not have.3SG-PF any problema
'There's no problem.'

b. Había un perro en el jardín. have.IMPF.3SG a dog in the garden

(Spanish)

'There was a dog in the garden.'

Existential sentences also stand out for their non-canonical subjects, which diverge from canonical subjects with respect to their marked postcopular position, as well as with respect to their ability to control agreement on the copula (cf. Beaver et al. 2005, Bentley 2010, 2013). In particular, Bentley (2013) distinguishes three agreement patterns in existentials: consistent agreement, invariant lack of agreement, and differential agreement. The first pattern is found in the majority of Friulian dialects (Haiman and Benincà 1992; cf. (8a)), in Italian $(10 \mathrm{a})$, in a number of central and southern Italo-Romance dialects $(6 \mathrm{c}, 7 \mathrm{c})$, in Corsican, in most Campidanese and some Nuorese Sardinian dialects (cf. § 5), and in Romanian (6a). Invariant lack of agreement is found in French (10b), Ladin and some Romansh dialects (Manzini and Savoia 2005: III, 40-42), some extreme southern Italo-Romance dialects spoken in Calabria and Salento (10c), and Brazilian Portuguese (8d):

(10) a. Ci sono molti semi in questa frutta.

$$
\mathrm{PF} \text { be.3PL many seeds in this fruit }
$$

b. Il y a plusieurs pépins dans ce fruit. EXP PF have.3SG several seeds in this fruit
c. Intru a sta frutta ave tanti samenti. in to this fruit have.3SG many seeds
'There are many seeds in this fruit.'

(Italian)

(French)

(Soleto, Salento)

Differential agreement is sensitive to a specificity scale ranging from first and second person pronouns, which are maximally specific, to non-specific noun phrases. In most northern Italo-Romance varieties and in Florentine, only pronominal pivots consistently trigger agreement on the existential copula. In some central Italo-Romance dialects, including Tuscan varieties other than Florentine, agreement failure with non-pronominal pivots is frequent but not invariantly absent (cf. §3.1). In the northern and central dialects showing 
differential agreement the copula is always ESSE; whereas in other varieties, such as Nuorese, Logudorese and archaic Campidanese Sardinian dialects, differential agreement correlates with copula alternation (cf. § 5; see Bentley 2013, Bentley, Ciconte and Cruschina in press for more details, including a comparison with other constructions featuring a postverbal subject and lacking agreement).

A first interesting correlation emerges from the patterns of variation presented above. Agreement between the pivot and the copula depends on the selected copula: existentials with STARE exhibit consistent agreement, copula HABERE does not generally agree with the pivot, while ESSE appears in both agreeing and non-agreeing patterns. Cases of agreement with HABERE have been reported for the Francoprovençal dialect spoken in Celle di San Vito, in Puglia (Manzini and Savoia 2005: III, 66), and for central Catalan dialects (Rigau 1997). In addition, in several varieties of Spanish, existentials are undergoing a grammatical change whereby haber has started to agree with the pivot (see Rodríguez Mondoñedo 2006, Brown and Rivas 2012, and references therein). I will return to these exceptional cases of agreement in have-existentials in section 5.

\section{Be-existentials in Italo-Romance}

The semantic link between existential propositions and canonical locative predications has often been described as a mere difference in the Topic-Comment articulation of the same underlying structure, as reflected by the fact that in many languages the distinction is only marked by a different word order (cf., e.g., Freeze 1992, 2001; see also Partee and Borschev 2002, 2007). In Romance, as well as in other languages, a sentence initial locative coda is not necessary in existentials, but some scholars have argued that, independently of the presence of a locative phrase within the sentence, the argument of the property denoted by the existential DP is always an implicit contextual domain or null argument (something intuitively similar to a location), and that the presence of an overt locative coda would simply contribute to the restriction of its identity (Francez 2007). Within this analysis of the pivot as predicate, existentials are not locative (contra Freeze 1992, 2001) because they contain no locative predicate. The idea of a null or implicit location as the argument of the existential predication has been formulated in various terms or with reference to somewhat different notions, such as Erteschik-Shir's (1997) stage topic and Kratzer's (1995) event argument (see also Hazout 2004 and Kallulli 2008). This null argument may also identify with the null locative argument postulated for unaccusative constructions (Benincà 1988, Saccon 1993, Pinto 1997, Tortora 1997, 2001, Sheehan 2006, 2010; see also Babby 1980, Rigau 1997, Partee and Borschev 2002, 2007, Leonetti 2008a, Parry 2010). In several languages, crucial evidence in favour of the idea of a null locative or, in general, of a parallelism between existential sentences and locative constructions comes from the presence of a locative proform. This element has been 'bleached' of its locative referential/deictic content, but, at least according to certain analyses (cf. Cruschina 2012), can be viewed as encoding the locative null argument of existentials or, depending on the language, as a merely lexicalized segment that has survived from a stage in diachrony where it played a genuine locative function (cf. Ciconte 2010). This 
demonstrates that, despite the similarity, a full assimilation between existentials and locatives is not tenable.

\subsection{Existential copulas and agreement}

In Italo-Romance, the most widespread existential copula is ESSE, which is found in the northern regions (Piedmont, Liguria, Lombardy, Veneto, Emilia-Romagna), in central Italy (Tuscany, northern Umbria, and northern Marche), as well as in the South (in Basilicata, except at the border with Puglia, in most of Salento, in Calabria, and in Sicily). In all these dialects ESSE is unsurprisingly the same copula employed in locative structures functioning as the link between the subject and the locative predicate. Central and southern Italian copula STARE can be considered to be a variant of ESSE both in its existential (11a, 12a) and locative predicative function (11b, 12b) (cf. Ledgeway 2008, 2009: Ch.16, and references therein). More specifically, this copula is used in southern Marche, southern Umbria, Abruzzo, Molise, Lazio, Campania, and Puglia (but not south of Lecce). Indeed, in those dialects where it is used in existentials, STARE is also normally selected as the locative copula:
(11) a. Ce sta le pantofole, sotto lu lettu. (Macerata, Marche) PF stay.3SG/PL the slippers under the bed
b. Le pantofole sta sotto lu lettu. the slippers stay.3SG/PL under the bed 'The slippers are under the bed.'
(12) a. Cə stannə e tuagliə nt'o cassettə. PF stay.3PL the towels in-the drawer
b. E tuagliə stann the towels stay.3PL in-the drawer 'The towels are in the drawer.'

No agreement variation emerges with STARE-existentials, where the copula consistently agrees with the pivot, while both agreeing and non-agreeing patterns are found in those dialects that select ESSE. ${ }^{9}$ A strong correlation also emerges between the presence of an expletive element and the lack of agreement. Northern Italian dialects may realize verb-subject agreement with a specific morphological inflection or form of the verb form; in case of a syncretic verb, especially in the third person, subject clitics can help to discriminate between the agreeing and the non-agreeing pattern (13a) -in a number of dialects both inflection and subject

9 A number of central dialects, especially in the Marche and in Abruzzo show a syncretic form for third person singular and plural (cf. sta in (11)). The systematic presence of agreement has been difficult to determine in a few dialects at the border with areas where distinct forms exist (e.g. in Castiglione Messer Marino) or in which a strong influence from Italian is yielding a new specialized ending for the plural (e.g. in Pescara), since in these dialects apparent cases of lack of agreement can be attributed to the optionality of the syncretic form. A similar case of syncretism is found in Veneto, although in these dialects the person feature of the verb can be determined on the basis of the co-occurring subject clitic, as in (13) and (15a). 
clitics may mark number agreement (14a) (cf. Poletto 2000, Manzini and Savoia 2005, a.o.). Whenever an expletive clitic is present in the sentence, however, the verb agrees with this element, rather than with the postverbal subject. This also occurs in existential sentences, where the copula agrees with the expletive subject clitic, but not with the pivot (13b, 14b):
(13) a. I sugaman i
é te la casèla. the towels SCL.M.3PL be.3PL in the drawer
b. L'é i sugaman te la casèla. EXP-be.3SG the towels in the drawer
(Belluno, Veneto)
(14) a. I sciügamai i sun inta cantera. (Genoa, Liguria) the towels SCL.M.3PL be.PL in-the drawer
b. U gh'è i sciügamai inta cantera EXP PF-be.3SG the towels in-the drawer

The expletive clitic, which is usually homophonous to the third person masculine subject clitic, disappears with personal pronouns, in which case an agreeing subject clitic is found (whenever available in the given dialect), although variation exists with respect to third person pronouns, which may or may not allow the expletive construction depending on the specific dialect (cf. Bentley 2013): ${ }^{10}$
a. Maria no la
é sola. Te
(Belluno, Veneto) Maria not SCL.F.3SG is alone SCL.2SG be.2sg you
L'é lori.
EXP-be.3 they
(Genoa, Liguria)
b. Maria l'e no sola. Ti gh'e ti / Ghe sun gli atri.
Maria SCL.F.3SG-is not alone SCL.2SG PF-are you PF are the others
'Mary is not alone. You will be there / They will be there.'

Non-agreeing patterns are also found in central varieties, and in particular in Tuscan dialects, where lack of agreement is a generalized phenomenon involving postverbal focal subjects $(16 b, 17 b)$ (cf. Nocentini 1999). Florentine presents a similar pattern to the northern dialects with respect to pronominal pivots, which require agreement (16c). For many speakers of other Tuscan varieties either the agreeing or the non-agreeing option is generally acceptable $(17 \mathrm{~b}):^{11}$
(16) a. Le pantofole le son sotto il letto. (Florence, Tuscany) the slippers SCL.F.3PL be.3PL under the bed
b. (E) c'è le pantofole, sotto il letto EXP PF-be.3SG the slippers under the bed

\footnotetext{
10 One may wonder whether these are locative structures, rather than genuine existentials. I will not deal with this issue here, but see Cruschina $(2012,2014)$, Bentley (2013), Bentley, Ciconte and Cruschina (in press) for discussion.

11 See Bentley, Ciconte and Cruschina (2013b) for the special case of microvariation concerning subject agreement in partitive existential structures.
} 
$\begin{array}{lllllll}\text { c. La Maria la } & \text { unn'è sola. } & \text { Tu ci } & \text { sei } & \text { te. } \\ \text { the Maria } & \text { SCL.F.3SG } & \text { not-is } & \text { alone } & \text { SCL.2SG PF } & \text { be.2SG } & \text { you }\end{array}$

(17) a. Le ciabatte so' sotto il letto. the slippers be.3PL under the bed

b. Ci so' / c'è le ciabatte, sotto il letto PF-be.3PL PF-be.3SG the slippers under the bed

This variation with respect to agreement does not really support the idea of the similarity between existentials and locatives, since agreement with the precopular subject is always obtained in locative predications, with no deviation from the expected behaviour (13a, 14a, 16a, 17a). In this respect, the existentiallocative parallelism appears to be stronger in those dialects using STARE as existential copula, which display consistent agreement. The observed patterns of agreement with be-existentials, on the contrary, undermine the hypothesis that the two constructions are marked by resemblance and have similar characteristics, although they may well be due to independent properties such as the use of an expletive construction -note that the combination of an existential expletive construction and copula STARE is not attested-or the special features of existential pivots. Indeed, the postcopular position of the existential pivot openly contrasts with the obligatory preverbal position of the subject in locative predications, and several pragmatic and semantic differences have been attributed to this distinction (cf. Lambrecht 2000, Beaver et al. 2005, Bentley 2010, 2013).

\subsection{The proform in be-existentials}

Even if the synchronic role of the proform in existential sentences is still controversial and object of debate, its historical derivation and etymology from the locative clitic is less disputed. Compelling evidence that the proform was locative when it first emerged is provided by early Tuscan, where the proform occurs in complementary distribution with a locative phrase (Ciconte 2009, 2010). In (18a) the locative proform anaphorically resumes a locative complement mentioned in the previous sentence, while in (18b) a locative phrase appears within the same sentence, and the proform is therefore missing:

(18) a. Mia dama vi sarà, e saravvi tanta buona gente. my lady PF be.FUT.3SG and be.FUT.3SG-PF much good people 'My lady will be there, and many good people will also be there.'

b. Era una Guasca in Cipri.

(early Tuscan: Novellino, LI)

be.IMPF.3SG a Gascony-woman in Cyprus

'There was a woman from Gascony in Cyprus.'

As a result of grammaticalization, the proform loses its locative meaning and acquires a more abstract and generalized function, being reanalysed as the spell-out of the abstract spatiotemporal argument of the existential predication (cf. $\S 4.2$ ). The co-occurrence with a locative phrase within the clause becomes thus possible. Ciconte (2011) shows that, among the early Italo-Romance vernaculars, 
the strict complementarity is first lost in Sicilian, where this change predates the fourteenth century:

(19) Chi fu in Sicilia grandi fami.

PF be.PST.3SG in Sicily big hunger

(old Sicilian)

'There was much hunger in Sicily' (Conquesta, XVIII, 3)

The proform has also unmistakable locative origins in the evidence from the modern Italo-Romance dialects. On the basis of a survey of 115 ItaloRomance dialects, Cruschina (2014) draws the following empirical generalizations with regard to the relation between the proform and the locative clitic in unambiguously locative contexts. First, as already mentioned, not all dialects display a proform in the existential construction, in the same way as not all dialects have a locative clitic; however, whenever a locative clitic is available in the language, the proform is always morphologically identical to it (20). Second, all dialects without a proform also lack a locative (resumptive) clitic (21). The reverse of this second generalization, however, does not hold true: a few dialects with no locative resumptive clitic but with a proform are attested (22). Whether the latter should be treated as cases of spontaneous development or of structural borrowing from contact languages is difficult to determine, even though the latter hypothesis seems more plausible, at least in some cases (I will briefly mention the case of southern Calabrian dialects in section 4).

(20) a. Nni sta frutta ci su(nnu) ossa assà. in this fruit $\mathrm{PF}$ be.3PL seeds much 'In this fruit there are many seeds.'

b. $\hat{A}$ scola, ci vaju tutti i jorna. to-the school there.CL go.1SG all the days

'To school, I go every day.'

(21) a. Jind'a sta fruttə $\varnothing$ stè a səmendə assè. (Polignano, Puglia) in-to this fruit stays the seed much

b. A la scòughə, Ø vòuchə tuttə $i$ dù. to the school go.1SG all the days

(22) a. Intra sta frutta nci suntu tanti nozzuli. (Taviano, Salento) in this fruit $\mathrm{PF}$ are many seeds

b. A la scola, $\varnothing$ vàu tutti li giurni. to the school go.1SG all the days

Irrespective of the etymology and of the partial or full morphological identity, the existential proform of modern Romance is non-referential, in the sense that it does not have the deictic and spatial power to refer to a location, which is typical of locative pronouns proper. If the existential proform had the same locative function as the locative clitic, it should then be incompatible with a co-referential locative phrase within the same clause, because this would yield an illegitimate case of clitic doubling. A locative resumptive clitic is only grammatical with a dislocated locative PP (23a), but not with a focal one (23b) 
(e.g. in the answer to the question where did you go yesterday? or what did you do yesterday?). On the contrary, the existential proform never gives rise to clitic doubling effects $(24,25)$, which are in fact not tolerated in the majority of the Romance languages: ${ }^{12}$

(23) a. Ci sono andato ieri, a Roma.

PF be.1SG gone yesterday to Rome

(Italian)

'I went to Rome yesterday'

b. (*Ci) sono andato a Roma.

PF be.1SG gone to Rome

'I went to Rome'

(24) a. $\mathrm{Ci}$ sono molti fiori in giardino.

PF be.3PL many flowers in garden

b. Il y a beaucoup de fleurs dans le jardin. (French) EXP PF have.3SG many of flowers in the garden

'There are many flowers in the garden'

(25) a. Pare che ghe sia a neve in paese. (Padua, Veneto) seem.3SG that $\mathrm{PF}$ be.SBJV.3SG the snow in town

(Castelluccio Inferiore, Basilicata)

b. Parə ca c'è a nivə nd'o paìsə.

seem.3SG that PF-is the snow in-the town

'It seems that there's snow in (the) town.'

The existential proform is therefore not locative, and (Italo-)Romance existentials are not locative constructions because they involve no locative predicate. This may be seen as the result of a process of grammaticalization that has affected the originally locative pronoun, converting it into a pro-argument spelling out the abstract argument that provides the spatiotemporal coordinates of the existential predication (Cruschina 2012, drawing on Francez 2007).

12 See Cruschina (2012) for further discussion and examples, and for the claim that structures with definite DPs must be interpreted as locatives or as exceptional constructions, e.g. sentences with a strong deictic anchoring of 'here' and 'now' or presentational sentences (cf. also Leonetti 2008a, Casalicchio 2013, Villalba 2013). Note that clitic resumption should not be confused with clitic doubling: the former refers to the presence of a clitic co-referential with a dislocated topic constituent, while the latter indicates the co-occurrence of the clitic with the corresponding core-internal constituent. Although it is generally barred in Romance, clitic doubling is admitted to varying extents in Spanish and Romanian, and is also possible with personal pronouns and/or with dative arguments in several other varieties (Jaeggli 1982, 1986a, Benincà 1988, 2001, Dobrovie-Sorin 1990, 1994, Torrego 1998, Kayne 2000: Ch. 9, Anagnostopoulou 2006). 


\section{Italo-Romance have-existentials}

Copula HABERE is found in Sardinia (especially in the Nuorese and Logudorese dialects), in a small part of Salento (the so-called Grecia Salentina, in the province of Lecce) and in southern Calabria (in the provinces of Reggio Calabria, Vibo Valentia and Catanzaro). While TENERE has replaced HABERE as a lexical verb of possession in several southern Italo-Romance dialects (cf. Ledgeway 2008, 2009: Ch.16 and references therein), including the Salentino dialects under discussion, this substitution occurs in no existential construction (in Romance, TENERE is only found in Brazilian Portuguese existentials; see, e.g., Avelar 2009). Sardinian existentials will be discussed in section 5; here I focus on the existential constructions found in Salento and in Southern Calabria that are characterized by the fact that the copula is an outcome of Latin HABERE. ${ }^{13}$ In the Salentino dialects investigated (Soleto and Martano, in the province of Lecce [LE]), the use of HABERE in existentials is regular and systematic:

(26) a.

Ave soruta intru la cucina.

(Soleto, LE)

has sister-your in the kitchen

'Your sister is the kitchen (lit. There's you sister in the kitchen).'

b. Ave doi cristiani alla porta.

has two people at-the door

'There are two people at the door.'

c. Intru allu ciardinu ave nu musciu biancu. in to-the garden has a cat white

'In the garden there's a white cat.'

In these dialects, HABERE is only used as auxiliary verb (27) and as the copula of the existential construction (in all tenses and moods) $(26,28)$, while the

13 Interestingly, these areas are linguistically known for their Greek substratum (cf., e.g., Rohlfs 1977). In the Greek dialects spoken both in southern Calabria (i, ii) (Rossi Taibbi and Caracausi 1959: 248, 254) and in Salento (iii) (source: $<$ http://www.greciasalentina.org/L_Html/dialoghi.htm>), the equivalent of the copula have and an accusative pivot are used in the existential construction:

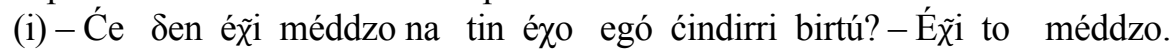
and not has means that have I that virtue has the means - 'Isn't there a way for me to have that power? - There's a way.'

(ii) Éna vyágg í íxe énan ándra ce mian ginéka cé $\delta$ en íxai pedia. one time had.3SG a man and a woman who not had children 'Once upon a time there were a man and a woman who didn't have any children.'

(iii) $\mathrm{E}$ furtuna arte wrai ene ka echi o kkumpare Loici ma ma. the fortune tonight is that has the compare Luigi with us 'We are lucky tonight to have (lit. that there is) our friend Luigi with us.'

One may thus hypothesize that the have-existentials found in the ItaloRomance dialects spoken in the same areas have been inherited from or reinforced by the Greek substratum. Synchronically, however, in southern Calabria the extension of the region where have-existentials are attested is much wider than the limited area where the Greek dialects have survived. A satisfactory answer to this question certainly requires further diachronic investigation. 
verb derived from Latin TENERE is used as lexical have to express possession (29). Comparing the existential copula with the auxiliary forms, it becomes evident that existential ave coincides with the third person singular:

(Soleto, LE)

(27) 1SG Iu aggiu mangiatu. 1PL Nui imu mangiatu. ('have/has eaten')

2SG Tie ai mangiatu. 2PL Vui iti mangiatu.

3SG Quiddru/a ave mangiatu. 3PL Quiddri annu mangiatu.

(28) a.

Avìa doj a la porta: no sapìa ci $\begin{gathered}\text { (Soleto, } \mathrm{LE} \text { erane } \\ \text { end }\end{gathered}$

had.PST.3SG two at the door not know.IMPF.1SG who were

'There were two people at the door: I didn't know who they were.'

b. Avvire do ove intra a lu frigoriferu.

have.COND.3SG two eggs in to the fridge

'There should be two eggs in the fridge.'

c. Tocca (cu) aggia camise intru lu cassettu. must.3sG that have.SBJV.3SG shirts in the drawer

'There must be shirts in the drawer.'

d. Pote avire quarche problema.

can.3sg have.INF some problem

'There might be some problem.'

(29) a. Tengu doi figli.

(Soleto, LE)

have.1SG two children

'I've got two children.'

b. Quiddhi tenene na machina russa

they have.3PL a car red

'They've got a red car.'

The evident distinction between existentials and possessives with respect to the copula/verb selected demonstrates that a full assimilation between the two constructions is not possible. As already mentioned, the aim of the present study is not to argue in favour of the identification between the structures, but rather to show that certain morphosyntactic properties of the existential structures are better understood if considered as mirroring and reflecting the features of a source construction. Having examined and compared Salentino copulas, the next step is to comment on the proform: no proform ever shows in the Salentino existential constructions, as expected in dialects which lack a locative clitic in general (cf. $\S 3.2$ ):

(30) a. Intra lu cassettu $\varnothing$ misi li sciucamani puliti.

(Soleto, LE) in the drawer put.PST.1SG the towels clean

'I put the clean towels in the drawer.'

b. A la scola $\varnothing$ vàu tutti li giurni. to the school go.PRS.1SG all the days

'I go to school every day.' 
More irregular and fragmentary is the situation in southern Calabria. In all dialects examined (Reggio Calabria, Bova Marina, Agnana Calabra, and Gioia Tauro in the province of Reggio Calabria [RC], Acquaro and Ciano in the province of Vibo Valantia [VV], Squillace and Montauro in the province of Catanzaro [CZ]), have-existentials alternate with a construction with a copula resulting from Latin ESSE. The co-existence and the precise distribution of these two structures are not easy to explain, but it is reasonable to believe that they are the result of the influence and pressure from standard Italian on to these dialects, and of sociolinguistic factors (cf. Sorrenti in prep.):

(31) a.

$$
\begin{aligned}
& \text { Non c'è / ndavi nenti. } \\
& \text { not PF-is has nothing } \\
& \text { 'There's nothing.' }
\end{aligned}
$$

b. C'è / ava nu bagnu?

PF-is has a bathroom

(Reggio Calabria)

'Is there a bathroom?'

No locative proform is used in the existential construction with HABERE, while the proform (n)ce is always used in conjunction with copula ESSE. This piece of data goes in favour of the hypothesis that the have-existential is the genuine construction in these dialects, since they generally lack a locative clitic in other contexts (32). The proform in be-existentials must therefore have been borrowed as part of the construction:
(32) A skola
$\varnothing \quad$ vaju
ogni jornu.
to school
go.PRS.1SG every day
'I go to school every day.'
(Reggio Calabria)

Some of these dialects, mostly in the province of Reggio Calabria, show an incorporated element - etymologically from Latin INDE 'from there', but synchronically with no locative meaning- not only with the existential copula but also with the auxiliary and lexical 'have' (similarly to the auxiliary clitics discussed in Benincà 2007):

(33) a. Si u ndavía sapútu, venía.

if it.CL had.1SG known come.IMPF.1SG

'If I had known, I would have come.'

(Roccella Jonica, RC)

(Agnana Calabra, RC)

b. Mi ndavivi diciutu ka c'eri puru tu.

to-me.CL had.2SG said that PF-were also you

'You had told me that you'd be there too.'

c. Ndavi u ndavi di cammise nt'o cassettu.

has that has some shirts in the drawer

'There have to be some shirts in the drawer.' 
(34) Ndavìa na vota a n' omu ki ndavìa du figghioli. had.3SG one time ACC a man who had.3SG two children

'Once upon a time, there was a man who had two children.'

Where no such incorporated proform is generally used, INDE seems to appear predominantly in partitive contexts, although its precise use is still not entirely clear for all dialects. In some dialects (e.g. Bova Marina, RC) avi and ndavi appear to be in free variation (cf. Bentley, Ciconte and Cruschina 2013b; see also Manzini and Savoia 2005: Ch.5). Unlike Salentino dialects, in southern Calabria HABERE is used both as auxiliary (33) and as lexical verb (35):
a. Aju du figghioli.
have.1SG two children
'I've got two children.'
they have a car red
'They've got a red car.'
b. Idi annu na machina russa.

(Squillace, CZ)

Displaying a morphologically third person singular copula, haveexistentials must be interpreted as impersonal constructions with a null subject, which surfaces as an expletive pronoun in non-null subject languages like French (cf. (5c) above). Therefore, the next question to be addressed is what the syntactic function of the pivot is. In the following section I will provide a characterization of the existential DP and of its object properties in the Salentino and Calabrian dialects under investigation.

\subsection{The object function of the pivot}

Unlike other Romance varieties employing copula HABERE in existentials, where the formal properties of the pivot cannot be determined clearly and unequivocally, in the have-existentials of these southern Italo-Romance dialects, the pivot is syntactically marked as the direct object. That the existential pivot of haveexistentials functions as a direct object has been independently claimed for Spanish (Suñer 1982) and for Catalan (Rigau 1994, 1997), and has also been hinted at for Italo-Romance (Manzini and Savoia 2005: III, 68-69). The Salentino and Calabrian dialects at issue provide three additional and incontrovertible pieces of evidence for this claim (cf. Bentley, Ciconte and Cruschina in press): (i) lack of agreement, (2) Differential Object Marking (DOM), and (iii) accusative clitic resumption.

First of all, the copula never agrees with the pivot, irrespective of its number and person features (36), and independently of its position in the sentence and of the topic-focus distinction (37). Lack of agreement is a property typical of objects, rather than subjects. ${ }^{15}$

\footnotetext{
14 From Vivaldi - Vivaio Acustico delle Lingue e dei Dialetti d'Italia, HumboldtUniversität Berlin: $<$ http://www2.hu-berlin.de/vivaldi/index.php>.

15 In some of the following examples, an Italian translation is provided besides the English one. Due to the different behaviour with respect to the Definiteness Effect, the English translation often structurally diverges from the original sentence in several respects. The Italian sentence, on the contrary, not only
} 
(36) a. Non te preoccupare: ava a mia. (Agnana Calabra, RC)

not 2SG.REFL worry.INF has ACC me

'Don't worry: I'll be there.' (Italian: ci sono io)

b. Ndava a vui chi m' aiutati?

has ACC you.PL who OCL.1SG help.2PL

'Will you be there to help me?' (Italian: Ci sarete voi ad aiutarmi?)

(37) a. Ave li stessi problemi a la Basilicata.

(Soleto, LE)

has the same problems in the Basilicata

'There are the same problems in Basilicata.'

b. Intra lu cassettu, li sciucamani, non l'ave.

in the drawer the towels not OCL.3PL-has

'In the drawer, there are no towels.'

(Italian: Dentro il cassetto, gli asciugamani, non ci sono.)

Secondly, in these dialects DOM is achieved by means of the prepositional marker ' $a$ ', depending on specific properties of the DP such as animacy and definiteness, and reflecting given properties of verb (cf. Bossong 1991, Leonetti 2004, 2008b, a.o.). With respect to the association between DOM and nominal properties, in particular the definiteness of the DP, the two groups of dialects differ significantly. In general, Salentino dialects differentially mark only the highest elements of the definiteness scale (i.e. first and second person pronouns $(38 \mathrm{a}, \mathrm{b})$, but not third person pronouns (38c), quantifiers (39a), proper names or definite DPs (39b)); while Calabrian dialects, in addition to all personal pronouns $(40,41 a)$ and proper nouns (41b), also display DOM with definite DPs (42) and, occasionally, in some dialects, with indefinite specific DPs $(43,44):^{16}$

$$
\begin{array}{lll}
\text { La Maria no stae } & \text { sula. } \\
\text { the Mary not stay.3SG } & \text { alone }
\end{array}
$$

(Soleto, LE)

'Mary is not alone.'
a. Ave a tie.
has ACC you.SG
'You'll be there.'
b. Ave a nui. has ACC us
'We'll be there.'
c. Ave $(* a)$ quiddhi. has ACC them 'They'll be there.'
Ci siamo noi.
Ci sono loro.

Italian: Ci sei tu.

(39) a. Nonn' ave (*a) nisciunu.

not has ACC no one

'There's no one.'

b. Ave (*a) la Maria / soruta.

has ACC the Mary sister-your

'Mary / Your sister is here/there.' (Italian: C'è Maria / tua sorella.)

reflects better the structure of the dialectal example, but was also the input sentence that our informants were asked to translate.

16 On the relationship between DOM and the scale of definiteness, see Aissen (2003), among others. On the variation of southern Calabrian dialects with respect to DOM, see also Sorrenti (in prep.). 
(40) Maria non è sula.
a. $\operatorname{Av}(i)$ a mia.
b. $\operatorname{Av}(i)$ a tia.
c. $\operatorname{Av}(i)$ a nui.
d. Av(i) a iddi.
(3PL)

(Bova Marina, RC)

(41) a. Ndavi ad iju /ija che t' has ACC him/her who OCL.2SG help.3SG

'He/she'll be there to help you' (Italian: C'è lui/lei che ti aiuta.)

b. Guarda: ndavi a Maria!

look has ACC Mary

'Look: Mary is here!' (Italian: Guarda: c'è Maria!)

(42) a. Ndavi a to soru nt'a cucina. has ACC your sister in the kitchen

'Your sister is in the kitchen' (Italian: C'è tua sorella in cucina.)

b. Ava a u dottori chi n' aspetta. Sbrigamuni. (Montauro, CZ) has ACC the doctor who us wait.3SG hurry.IMP.1PL

'The doctor is waiting for us. Let's hurry!'

(Italian: C'è il dottore che ci aspetta. Sbrighiamoci.)

(43) Ndavìa na vota a n'omu ki ndavìa du figghioli. had.3SG one time ACC a man who had.3SG two children 'Once upon a time, there was a man who had two children.'

(44) Ndavi sulu a du perzuni ca mi vonnu beni. (Agnano Calabra, RC) has only ACC two people who OCL.1SG want.3PL well 'There are only two people who love me.'

The different behaviour between Salentino and Calabrian dialects with respect to DOM and its correlation with the definiteness of the pivot is summarized in Table 1:

\begin{tabular}{|l|c|c|}
\hline \multicolumn{1}{|c|}{ Human } & \multicolumn{2}{c|}{ DOM with 'a' in HABERE existentials } \\
\hline \multicolumn{1}{|c|}{ Definiteness Scale } & SALENTO & CALABRIA \\
\hline Personal Pronouns [1st, 2nd] & + & + \\
\hline Personal Pronouns [3rd] & & + \\
\hline Proper Nouns & & + \\
\hline Definite NPs & & + \\
\hline Indefinite Specific NPs & & $(+)$ \\
\hline Indefinite Non-specific NPs & & \\
\hline
\end{tabular}

Table 1: Definiteness Scale and Differential Object Marking

DOM also depends on the (degree of) transitivity of the verb. Possessive have is generally defined as a low-transitivity verb and is located at the bottom of 
the Transitivity Scale (for parameters of transitivity, see Hopper and Thompson 1980, Tsunoda 1985: 388, Torrego 1999). In languages that have both a transitive verb of possession and DOM, the object of have can be expected to be left unmarked in conditions in which the object of typical transitive verbs is marked (cf. von Heusinger and Kaiser 2007 for Spanish). ${ }^{17}$ In Romance only a few exceptions exist to this generalization: in possessive structures, DOM is only found with pronouns and with secondary predication (cf. Laca 1987, Leonetti 2004, 2008b for Spanish; Ledgeway 2009 for Neapolitan). The same holds true for the possessive predications in the Salento and Calabrian dialects under examination, though subject to the nominal definiteness restrictions mentioned above. The preposition 'a' marks the object of a possessive sentence with HABERE only with personal pronouns $(45 \mathrm{a})$ and in conjunction with a secondary predicate $(45 \mathrm{~b}, \mathrm{c})$ :
(45) a. I me genitori non ennu suli, annu a nui. (Bova Marina, RC) the my parents not are alone have.3PLACC us
'My parents are not on their own, they've got us.'
b. Ndaju a me frati malatu.
have.1SG ACC my brother ill
'My brother is ill (lit. I have my brother ill).'
c. Avi a so matri a lu spitali.
has ACC his mother at the hospital

'His mother's in (the) hospital (lit. He has his mother in the hospital).'

What is important to notice here is that both in the Salentino and in the Calabrian dialects the extent of DOM with HABERE existentials seems to be the same as with other transitive verbs: in Salento DOM is limited to first and second person pronouns (including with higher transitivity verbs such as 'know', 'see', 'meet', 'kill'), while in Calabria DOM is more widespread across verb types and involves all but non-specific DPs. ${ }^{18}$

The final piece of evidence for the object coding of the pivot in the haveexistentials of these dialects comes from clitic dislocation: ${ }^{19}$

17 Spanish HABERE existentials never exhibit the accusative preposition 'a' (Habia $\left({ }^{*} a\right)$ una enfermera, 'There was a nurse', cf. Leonetti 2004, 2008b). According to Suñer (1982), these are impersonal and subjectless constructions, so there is no need for DOM, in the sense that there is no need to distinguish between subject and object. Note also that the morphologically accusative resumptive clitics found with this construction in Spanish are in fact partitive because they pick up indefinite DPs: -Hay brujas? -Sì, las hay, -'Are there witches? -Yes, there are' (cf. Longa, Lorenzo \& Rigau 1998 for the idea of clitic recycling).

18 Two possible explanations for the presence of DOM in existentials come to mind. First, it could be that, unlike possessive predications, DOM in Italo-Romance HABERE existentials reflects a high degree of transitivity. Alternatively, it could be postulated that, like the possessive structure exhibiting DOM, secondary predication is also at play in HABERE existentials (see $\S 4.2$; see also Kallulli 2008 for the claim that also English there-existentials involve secondary predication). was attested in the Calabrian dialects with respect to this phenomenon, in that not all dialects resorted to a resumptive clitic in the contexts that I am describing here. Even though not systematically, this phenomenon is indeed present in these 

(46) - T' ave a la festa? - Sì, m' ave. (Martano, LE) OCL.2SG has to the party yes OCL.1SG has - 'Will you be (there) at the party? -Yes, I will.' (Italian: - Ci sarai alla festa? - Sì, ci sarò.)
(47) Non l' ave, soruta, intra l' ufficiu. not OCL.3SG has sister-your in the office 'Your sister isn't there, in the office' (Italian: Non c'è, tua sorella, in ufficio.)

When the pivot is implicit or salient in the context and is being restored within the sentence in the form of a pronominal clitic (46), or when it is dislocated either to the left or to the right of the core sentence (47), a resumptive accusative clitic shows on the verb.

\subsection{Catching up with the semantics: the agreeing pattern}

In this section I propose a preliminary analysis of the differences and similarities between existentials and their source constructions. I will hypothesize that, for Italo-Romance, these differences can be described in terms of a path of grammaticalization and linguistic change. However, in the absence of supporting evidence for a historical derivation, the same analysis of the relationship between existentials and their source constructions could well be formulated and understood in terms of an independent and parallel development.

If the meaning of locatives with copula be can be described in terms of the presence or existence of an argument $X$ (the theme) with reference to a second argument $\mathrm{Y}$ (the location) (i.e. $\mathrm{X}$ is in $\mathrm{Y}$, cf. (48a)), possessive have has been derived from be through a step of grammaticalization and abstraction which in some analyses involves the incorporation of a preposition (Benveniste 1966, Freeze 1992, Kayne 1993, Heine 1997, Bentley \& Cruschina forthcoming): in the possessive structure, then, Y (the location) possesses X (the theme) $(48 \mathrm{~b}){ }^{20}$ The development of existentials requires the suppression of one of the two arguments (49), which is syntactically absorbed as an impersonal expletive or null subject, and semantically replaced by an abstract null argument providing the spatiotemporal coordinates for the predication (cf. Bentley and Cruschina forthcoming): ${ }^{21}$

dialects (cf. Manzini \& Savoia (2005: III, 69) for additional examples of accusative clitic resumption in these dialects; see also Sorrenti in prep.). decades, and is found in several theories of argument structure (Jackendoff 1972, 1983, 1990, Croft 1990, Foley and Van Valin 1984: 53).

In this grammaticalization process have has certainly lost part of its lexical meaning when it started appearing in have-existentials. The question of the exact nature of its null subject remains open. It could be assumed that it is an impersonal or expletive subject (cf. Suñer 1982 for Spanish, Rigau 1994, 1997 for Catalan, Manzini and Savoia 2005: Ch.5), or else, a quasi-argument, like with weather expressions (cf. Kayne 2008 for French). Another possibility is that it instantiates an arbitrary pro with an existential non-referential and non-anaphoric reading (cf. Jaeggli 1986b, Cabredo Hofherr 2006). I leave this issue aside for future research, but it must be noted that in some dialects of English, besides the impersonal 
(48) a. LOCATIVE (location, theme)

b. POSSESSIVE (possessor, possessee/theme)

\section{EXISTENTIALS}
a. $\quad$ I. be-Loc' $(Y, X) \rightarrow$ II $\sim$ be-Loc' $(\varnothing, \mathrm{x})$

b. I. be-with' (Y, X) $\rightarrow$ II $\sim$ be-with' $(\varnothing, \mathrm{x})$

A final step of grammaticalization involves the sole participant $\mathrm{X}$ of the existential construction, which shows properties that are unusual for a proper argument (cf. Beaver, Francez \& Levinson 2005, Bentley 2013). Following Francez (2007), I assume that the pivot is a property, which functions as the predicate of the null argument $\varnothing$ in order to yield the existential proposition (cf. also Williams 1994 and Hazout 2004 for hypothesis that the pivot is the predicate of an impersonal construction with an expletive subject). We have already seen that in existentials the location Y may resurface as a semantically 'bleached' proform, most probably acting as a pro-argument or a link to the spatiotemporal null argument. In this respect, the function of the existential proform can be compared to that of the proform found in the possessive constructions of some Italo-Romance varieties, which is also etymologically locative and generally identical to the existential proform in the corresponding varieties (see La Fauci \& Loporcaro 1993, 1997, Moro 1998, Benincà 2007, Bentley \& Ciconte forthcoming):
SCL.3PL PF have.3PL the POSS to do
'They have their things to do' (Lurà 1987: 142)
a. I gh' annu 1 sò da fá.
b. Non b'-amus mákkina.
not PF-have.1PL car
'We have no car' (Jones 1993: 59)
c. C'ho tre figli.
PF-have.1SG three children
(Mendrisiotto, Ticino)
(Nuorese Sardinian)
'I have three children.'
(colloquial Italian)

In line with the analysis of the existential proform as a pro-argument providing the spatiotemporal coordinates of the existential predication, this clitic can be analysed as the marker of an abstract argument which locates the possessive predication in space and time (Benincà 2007: 42). In this case, though, the latter type of predication would be secondary to the chief possessive predication. The presence of DOM effects with some have-existential may well be

pronoun it, the arbitrary pronoun they is attested (cf. Green 2002: 80f. for African American English, as well as for examples from Creoles, citing Bickerton 1981):

(i) a. It got some coffee in the kitchen. (African American English)

b. It have some coffee in the kitchen.

c. Dey got some coffee in the kitchen.

d. Dey have some coffee in the kitchen. 'There is some coffee in the kitchen.'

(ii) Dem get wan uman we get gyal-pickni. (Guyanese Creole) they have a woman who have young daughter 'There is one woman who has a daughter' 
due to a residual of this secondary predication, corroborating once more the idea that possessives are the source of this kind of existential constructions (cf. $\S 4.1$ ).

Given the relatively high number of resemblances with respect to the source construction, one may wonder why the development of existentials has not affected all elements and grammatical properties of the construction, in line with the semantic change. Under the hypothesis that both be-existentials and haveexistentials have converged to a common meaning, the persistence of their distinguishing properties that reflect their different source construction are somehow unexpected. This syntax-semantics mismatch may explain the special and peculiar properties of the existential pivot across languages, which behaves as a "bad subject" or an "atypical" object, or which in fact displays a mixed behaviour (cf. Lambrecht 2000). Because of this mismatch, in a construction where the pivot functions semantically as the predicate of the existential proposition, the morphosyntactic properties typical of arguments (e.g. agreement control and object marking) are very unstable.

Further processes of grammatical change have affected the residual properties of existentials. This is what has happened, or is currently happening, in the haveexistential construction in central Catalan dialects (Rigau 1997: 403) and in several varieties of Spanish (Rodríguez Mondoñedo 2006: 329, Brown and Rivas 2012: 321, and references therein), where the pivot controls agreement on the copula:
a. Hi han
PF have.PRS.3PL the students
(central Catalan)
b. Hubieron fiestas en todos los pueblos menos en ése. have.PST.3PL celebrations in all the towns except in that 'There were celebrations in all towns except in that one'
c. Habían algunos libros de sintaxis en mi cuarto. have.IMPF.3PL some books of syntax in my room 'There were some books about Syntax in my room'

In these Spanish dialects, haber agrees with the sole nominal phrase of the existential construction, in an agreement pattern that co-exists alongside with the standard and more generalized invariant lack of agreement (see $\S 2$ ). This change has been analysed as the result of the reanalysis of the pivot as subject (Waltereit and Detges 2008, Brown \& Rivas 2012), although for other scholars the ability of the pivot to control agreement does not necessarily make it a subject (Rodríguez Mondoñedo 2006). Under the analysis defended here, the pivot functions as the predicate of the existential proposition. The issue of its superficial grammatical subject or object properties is thus orthogonal to its main role in the predication, and this oscillation between the two grammatical functions is not unexpected.

\section{Alternations in Sardinian}

In this section I briefly discuss two types of alternation found in some Sardinian dialects with respect to the copula and the proform occurring in the existential construction. Unlike the similar type of alternation found in southern Calabria (cf. 
$\S 4)$, which is not as systematic as to exclude the hypothesis that the current situation emerged as a result of language contact, copula selection in Sardinian (in the Nuorese, Logudorese and, historically, also in the Campidanese dialects) has long attracted the attention of linguists. It is generally related to the definiteness (or specificity) of the DP, so that copula have is used in combination with indefinite DPs (52), while be occurs with definite DPs (53) (cf. Jones 1993: 113, La Fauci \& Loporcaro 1997, Bentley 2004, 2011, and Remberger 2009):

(52) a. B'at metas frores in sa tanca.

PF-has many flowers in the meadow

b. ? Bi sun metas frores in sa tanca.

PF are many flowers in the meadow

'There are many flowers in the meadow.'

(53) a. *B'at sos prattos in mesa.

PF-has the plates in table

b. Bi sun sos prattos in mesa.

$\mathrm{PF}$ are the plates in table

'The plates are on the table.'

For the purposes of this paper, what is important to note is that copula alternation correlates with two significant properties, confirming the relationship with the relevant source construction: copula-verb agreement and the locative value of the proform. First of all, in Sardinian have-existentials the pivot never agrees with copula (54), while agreement is obligatory when copula be is selected (55): ${ }^{22}$

$$
\begin{aligned}
& \text { a. B'at tres pitzinnas. } \\
& \text { PF-have.3SG three girls } \\
& \text { 'There are three girls.' } \\
& \text { b. * B'an } \quad \text { tres pitzinnas } \\
& \text { PF-have.3PL three girls }
\end{aligned}
$$

(55) a. Bi sun sas pitzinnas.

$\mathrm{PF}$ be.3PL the girls

'The girls are there.'
b. *B'est sas pitzinnas
PF-be.3SG the girls

Second, it was observed by Jones (1993: 114) that the clitic bi has a tangible locative value when it occurs with the copula be. This idea is further developed in Remberger (2009) and in Cruschina (2012), in which it is claimed that Sardinian sentences with copula be are in fact locative structures. Independently of the precise nature of Sardinian be-existentials, the ungrammaticality of (56b) can be attributed to the locative nature of the proform

22 Given that have-existentials are incompatible with definite or specific pivots, neither DOM or accusative clitic resumption show in Sardinian. 
$b i$ and to its co-occurrence with a focal interrogative locative phrase within the same sentence, which gives rise to an offensive clitic doubling configuration: ${ }^{23}$

(56) a. In ube b'at metas frores?
where PF-has many flowers
'Where are there many flowers?'
b. *In ube bi sun sos prattos?
where PF are the plates
'Where are the plates?' (Jones 1993: 114)

Another interesting alternation in Sardinian dialects concerns the proform. During the process of grammaticalization to existential proform, the locative clitic seems to have acquired special functions, so that now a deictically neutral proform ( $b i$ in Nuorese and Logudorese dialects, $(n) c i$ in Campidanese dialects) alternates with a deictically marked proform: (n)che is speaker-oriented in Nuorese and Logodorese, wheras ddoi denotes distance from the speaker in Campidanese (Bentley 2011, Bentley, Ciconte \& Cruschina in press). This alternation explains the ungrammaticality of (57b) when $(n)$ che combines with a locative phrase that indicates distance from the speaker; by contrast, either proform is possible in (57a), which features a proximal demonstrative:

(57) a. In custa istrada (n)ch'/ b'at carchi domo. (Benetutti, Logudorese) in that road PF PF-has some house 'In this road there are some houses'

b. In cussa istrada *(n)che / bi sun sas cresias de SantuJuanne e... in that road PF PF are the churches of Saint John and 'In that road there are the churches of Saint John and...'

The deictic specialization of the proform (n)che does not imply that the construction has to be understood as a locative predication: as a matter of fact, (57a) does not predicate location. It actually suggests that the process of grammaticalization of the locative adverb into a non-referential and non-deictic existential proform has not come to completion in all Romance languages. ${ }^{24}$

\section{Conclusions}

In Italo-Romance existential constructions, copula alternation is not immaterial or the simple result of a historical accident. The selected copula correlates with a defined set of properties (concerning agreement, proform, and differential object marking) which show a relationship of continuity with respect to a source construction: locative predication for be-existentials, and possessive predication for have-existentials. On the one hand, these different patterns show the high degree of microvariation across Italo-Romance dialects. On the other, the

23 See the discussion of examples (23) and (24) above, and footnote 12.

24 Interestingly, as reported in Bentley (2011), in some Campidanese varieties, the deictic proform $d d o i$ / ddui has developed an optional evidential function, which indicates the lack of a first-hand visual source of information. 
differences and similarities attested reveal important aspects of the process of grammaticalization and semantic change that yielded existentials, and help us understand the synchronic syntactic and semantic makeup of the existential proposition. If the differences examined in this paper lead to the incontrovertible conclusion that existentials are synchronically different concerning their respective source construction, the grammatical similarities are just as irrefutable. Historically, the existential constructions of the Italo-Romance varieties derive from the reanalysis of either a locative or a possessive structure. Accordingly, the partial overlap and the apparent analogies should be regarded as the natural reflections of a persistent historical continuity with respect to the source construction or, in other cases, as the result of incomplete grammaticalization. The reference to a source construction does not necessarily have to be understood in diachronic terms across languages: it has been widely shown (cf. Lyons 1967, Clark 1978, Freeze 1992, Heine 1997, Koch 2012, a.o.) that, crosslinguistically, the relationship between locatives, possessives, and existentials provides the cognitive and semantic basis for a natural derivation of existentials out of or parallel to a locative or a possessive source construction.

\section{References}

Abbott, Barbara. 1993. "A pragmatic account of the Definiteness Effect in existential sentences". Journal of Pragmatics 19: 39-55. http://dx.doi.org/10.1016/0378-2166(93)90069-2

Abbott, Barbara. 1997. "Definiteness and existentials". Language 73: 103-108. http://dx.doi.org/10.2307/416595

Aissen, Judith. 2003. "Differential object marking: Iconicity vs. economy". Natural Language \& Linguistic Theory 21: 435-483. http://dx.doi.org/10.1023/a:1024109008573

Anagnostopoulou, Elena. 2006. "Clitic doubling". In M. Everaert, H. Van Riemsdijk, R. Goedemans and B. Hollebrandse (eds.), The Blackwell Companion to Syntax, Vol. I, 519-581. Oxford: Blackwell Publishing. http://dx.doi.org/10.1002/9780470996591.ch14

Avelar, Juanito. 2009. "On the emergence of TER as an existential verb in Brazilian Portuguese". In P. Crisma and G. Longobardi (eds.), Historical Syntax and Linguistic Theory, 158-175. Oxford: Oxford University Press. http://dx.doi.org/10.1093/acprof:oso/9780199560547.003.0010

Babby, Leonard. 1980. Existential Sentences and Negation in Russian. Ann Arbor, MI: Karoma Publishers.

Badía Margarit, Antonio. 1951. Gramática histórica catalana. Barcelona: Editorial Noguer, S. A.

Beaver, David, Francez, Itamar and Dmitry Levinson. 2005. "Bad subject: (Non-) canonicality and NP distribution in existentials". In E. G. and J. Howell (eds.), Proceedings of Semantic and Linguistic Theory XV, 19-43. Ithaca, NY: Cornell University Press.

Benincà, Paola. 1988. "L'ordine degli elementi della frase. Costruzioni con ordine marcato degli elementi". In L. Renzi (ed.), Grande grammatica italiana di consultazione. Volume 1: La frase. I sintagmi nominale e preposizionale, 129-194. Bologna: Il Mulino. 
Benincà, Paola. 1994. La variazione sintattica. Studi di dialettologia romanza. Bologna: Il Mulino.

Benincà, Paola. 2001. "The position of Topic and Focus in the Left Periphery". In G. Cinque and G. Salvi (eds.), Current Studies in Italian Syntax. Essays Offered to Lorenzo Renzi, 39-64. Amsterdam: Elsevier.

Benincà, Paola. 2007. "Clitici e ausiliari: gh ò, z é". In D. Bentley and A. Ledgeway (eds.), Sui dialetti italoromanzi. Saggi in onore di Nigel B. Vincent (The Italianist 27, Special Supplement 1), 27-47. King's Lynn: Biddles.

Bentley, Delia. 2004. "Definiteness effects: evidence from Sardinian". Transactions of the Philological Society 102 (1): 57-101. http://dx.doi.org/10.1111/j.0079-1636.2004.00130.x

Bentley, Delia. 2010. "Principles of subject markedness in Romance". Archivio Glottologico Italiano 95 (2): 152-189.

Bentley, Delia. 2011. "Sui costrutti esistenziali sardi. Effetti di definitezza, deissi, evidenzialità". Zeitschrift für romanische Philologie 127 (1): 111-140. http://dx.doi.org/10.1515/zrph.2011.005

Bentley, Delia. 2013. "Subject markedness and Definiteness Effects in Romance there sentences". Language 89 (4): 675-712. http://dx.doi.org/10.1353/lan.2013.0062

Bentley, Delia and Francesco Maria Ciconte. forthcoming. "Copular and existential constructions". In A. Ledgeway and M. Maiden (eds.), The Oxford Guide to the Romance Languages (Chapter 51). Oxford: Oxford University Press.

Bentley, Delia and Silvio Cruschina. forthcoming. "Existential Constructions". In S. Fisher and C. Gabriel (eds.), Manual of Grammatical Interfaces in Romance. Berlin: Mouton de Gruyter.

Bentley, Delia, Ciconte, Francesco Maria and Silvio Cruschina. 2013a. "Existential constructions in crosslinguistic perspective". Italian Journal of Linguistics 25: 1-13.

Bentley, Delia, Ciconte, Francesco Maria and Silvio Cruschina. 2013b. "Microvariation in subject agreement: The case of existential pivots with split focus in Italo-Romance". Italian Journal of Linguistics 25: 15-43.

Bentley, Delia, Ciconte, Francesco Maria and Silvio Cruschina. in press. Existentials and locatives in Romance dialects of Italy. Oxford: Oxford University Press.

Benveniste, Émile. 1966. Problèmes de linguistique générale, Vol. 1. Paris: Gallimard.

Bickerton, Derek. 1981. Roots of Language. Ann Arbor: Karoma.

Blasco Ferrer, Eduardo. 2003. "Tipologia delle presentative romanze e morfosintassi storica. Fr. c'est e prov. -i (estai, fai, plai)". Zeitschrift für romanische Philologie 119: 51-90.

http://dx.doi.org/10.1515/zrph.2003.119.1.51

Bossong, Georg. 1991. "Differential object marking in Romance and beyond". In Dieter Wanner and Douglas A. Kibbee (eds.), New Analyses in Romance Linguistics. Selected Papers from the XVIII Linguistic Symposium on Romance Languages 1988, 143-170. Amsterdam: John Benjamins.

Brown, Esther L. and Javier Rivas. 2012. "Grammatical relation probability: How usage patterns shape analogy". Language Variation and Change 24: 317-341. 
http://dx.doi.org/10.1017/s0954394512000154

Cabredo Hofherr, Patricia. 2006. "Arbitrary' pro and the theory of pro-drop". In P. Ackema, P. Brandt, M. Schoorlemmer and F. Weerman (eds.), Agreement and Arguments, 230-258. Oxford: Oxford University Press.

Casalicchio, Jan. 2013. Pseudorelative, gerundi e infiniti nelle varietà romanze: somiglianze (solo) superficiali e corrispondenze strutturali. Munich: LINCOM.

Cennamo, Michela. 2011. "Impersonal constructions and accusative subjects in Late Latin". In A. Malchukov and A. Siewierska (eds.), Impersonal constructions: A cross-linguistic perspective, 167-188. Amsterdam: John Benjamins. http://dx.doi.org/10.1075/slcs.124.06cen

Ciconte, Francesco Maria. 2009. "Pro-forms in existential constructions of Early Italo-Romance vernaculars". In G. Kaiser and E-M. Remberger (eds.), Proceedings of the workshop "Null-subjects, expletives, and locatives in Romance”, 183-198. Konstanz: Universität Konstanz, Konstanzer Arbeitspapiere des Fachbereichs Sprachwissenschaft (No. 123).

Ciconte, Francesco Maria. 2010. Existential Constructions of Early ItaloRomance Vernaculars. Ph.D. thesis, The University of Manchester. To appear in the Monograph Series of The Philological Society. Oxford: Wiley-Blackwell. http://dx.doi.org/10.1111/j.1467-968x.2011.01281.x

Ciconte, Francesco Maria. 2011. "The emergence and the reanalysis of the existential proform: Evidence from Early Italo-Romance". Transactions of the Philological Society 109 (3): 284-306.

Ciconte, Francesco Maria. 2013. "Argument realization and existential pro-forms in early Italo-Romance". In E. van Gelderen, J. Barðdal and M. Cennamo (eds.), Argument Structure in Flux: The Naples-Capri Papers, 549-566. Amsterdam: John Benjamins. http://dx.doi.org/10.1075/slcs.131.20cic

Clark, Eve. 1978. "Locationals: Existential, locative, and possessive constructions". In J. H. Greenberg, C. A. Ferguson and E. A. Moravcsik (eds.), Universals of Human Language, Vol. 4, 85-126. Stanford, CA: Stanford University Press.

Cornilescu, Alexandra. 2009. "Restructuring strategies of the Romanian verb $f i$ 'be' and the analysis of existential sentences". In G. Kaiser and E-M. Remberger (eds.), Null subjects, expletives and locatives in Romance, 199230. Konstanz: Universität Konstanz, Konstanzer Arbeitspapiere des Fachbereichs Sprachwissenschaft (No. 123).

Creissels, Denis. 2013. "Control and the evolution of possessive and existential constructions”. In E. van Gelderen, J. Barðdal and M. Cennamo (eds.), Argument Structure in Flux: The Naples-Capri Papers, 461-476. Amsterdam: John Benjamins. http://dx.doi.org/10.1075/slcs.131.17cre

Croft, William. 1990. Typology and Universals. Cambridge: Cambridge University Press.

Cruschina, Silvio. 2012. "Focus in existential sentences". In V. Bianchi and C. Chesi (eds.), Enjoy linguistics! Papers Offered to Luigi Rizzi on the Occasion of his 60th Birthday, 77-107. Siena: CISCL Press. Available online at: $<$ www.ciscl.unisi.it/gg60/> .

Cruschina, Silvio. 2014. "Existential and locative constructions in ItaloRomance”. L'Italia Dialettale 75: 55-80. 
Czinglar, Christine. 2002. "Decomposing existence: Evidence from Germanic". In W. Abraham and J-W. Zwart (eds.), Issues in Formal German(ic) Typology, 85-126. Amsterdam: John Benjamins. http://dx.doi.org/10.1075/la.45.06czi

Dobrovie-Sorin, Carmen. 1990. "Clitic doubling, wh-movement and quantification in Romanian". Linguistic Inquiry 21 (3): 351-397.

Dobrovie-Sorin, Carmen. 1994. The Syntax of Romanian. Comparative Studies in Romance. Berlin: Mouton de Gruyter. http://dx.doi.org/10.1515/9783110886597

Erteschik-Shir, Nomi. 1997. The Dynamics of Focus Structure. Cambridge: Cambridge University Press. http://dx.doi.org/10.1017/cbo9780511519949

Foley, William A. and Robert D. Jr. Van Valin. 1984. Functional Syntax and Universal Grammar. Cambridge: Cambridge University Press.

Francez, Itamar. 2007. Existential Propositions. Ph.D. thesis, Stanford University.

Freeze, Ray. 1992. "Existentials and other locatives". Language 68 (3): 553-595. http://dx.doi.org/10.2307/415794

Freeze, Ray. 2001. "Existential constructions". In M. Haspelmath, E. König, W. Oesterreicher and W. Raible (eds.), Language Typology and Language Universals: An International Handbook, Vol. 2, 941-953. Berlin: Walter de Gruyter. http://dx.doi.org/10.1515/9783110171549.2.10.941

Green, Lisa J. 2002. African America English. A Linguistics Introduction. Cambridge: Cambridge University Press. http://dx.doi.org/10.1017/cbo9780511800306

Haiman, John and Paola Benincà. 1992. The Rhaeto-Romance Languages. London: Routledge. http://dx.doi.org/10.4324/9780203992487

Hazout, Ilan. 2004. "The syntax of existential constructions". Linguistic Inquiry 35: 393-430. http://dx.doi.org/10.1162/0024389041402616

Heine, Bernd. 1997. Possession. Cognitive Sources, Forces, and Grammaticalization. Cambridge: Cambridge University Press. http://dx.doi.org/10.1017/cbo9780511581908

Hopper, Paul and Sandra Thompson. 1980. "Transitivity in grammar and discourse". Language 56: 251-299. http://dx.doi.org/10.1353/lan.1980.0017

Jackendoff, Ray. 1972. Semantic Interpretation in Generative Grammar. Cambridge, MA: MIT Press.

Jackendoff, Ray. 1983. Semantics and Cognition. Cambridge, MA: MIT Press.

Jackendoff, Ray. 1990. Semantic Structures. Cambridge, MA: MIT Press.

Jaeggli, Osvaldo. 1982. Topics in Romance Syntax. Dordrecht: Foris.

Jaeggli, Osvaldo. 1986a. "Three issues in the theory of clitics: Case, doubled NPs, and extraction". In H. Borer (ed.), The Syntax of Pronominal Clitics, 1542. New York: Academic Press.

Jaeggli, Osvaldo. 1986b. “Arbitrary plural pronominals". Linguistic Inquiry 4: 43-76. http://dx.doi.org/10.1007/bf00136264

Jones, Michael A. 1988. "Sardinian". In M. Harris and N. Vincent (eds.), The Romance Languages, 314-350. London: Routledge.

Jones, Michael A. 1993. Sardinian Syntax. London: Routledge. http://dx.doi.org/10.4324/9780203993804 
Kallulli, Dalina. 2008. "There is secondary predication in there-existentials". In C. B. Chang and H. J. Haynie (eds.), Proceedings of the 26th West Coast Conference on Formal Linguistics, 279-287. Sommerville, MA: Cascadilla Proceedings Project.

Kayne, Richard S. 1993. "Toward a modular theory of auxiliary selection". Studia Linguistica 47: 3-31. http://dx.doi.org/10.1111/j.1467-9582.1993.tb00837.x

Kayne, Richard S. 2000. Parameters and Universals. New York: Oxford University Press.

Kayne, Richard S. 2008. "Expletives, datives and the tension between morphology and syntax". In T. Biberauer (ed.), The Limits of Syntactic Variation, 175-218. Amsterdam: John Benjamins. http://dx.doi.org/10.1075/la.132.07kay

Koch, Peter. 2012. "Location, existence, and possession: A constructionaltypological exploration". Linguistics 50 (3): 533-603. http://dx.doi.org/10.1515/ling-2012-0018

Kratzer, Angelika. 1995. "Stage-level and individual-level predicates". In G. N. Carlson and F. J. Pelletier (eds.), The Generic Book, 125-175. Chicago, University of Chicago Press.

La Fauci, Nunzio and Michele Loporcaro. 1993. "Grammatical relations and syntactic levels in Bonorvese morphosyntax". In A. Belletti (ed.), Syntactic theory and the dialects of Italy, 155-203. Torino, Rosenberg \& Sellier.

La Fauci, Nunzio and Michele Loporcaro. 1997. "Outline of a theory of existentials on evidence from Romance". Studi italiani di linguistica teorica e applicata 26: 5-55.

Laca, Brenda. 1987. "Sobre el uso del acusativo preposicional en español". Romanistisches Jahrbuch 38: 290-312. http://dx.doi.org/10.1515/9783110244946.290

Lambrecht, Knud. 2000. "When subjects behave like objects: An analysis of the merging of $\mathrm{S}$ and $\mathrm{O}$ in sentence focus constructions across languages". Studies in Language 24 (3): 611-682. http://dx.doi.org/10.1075/s1.24.3.06lam

Ledgeway, Adam. 2008. "Sulla storia dei verbi copulari dei dialetti dell'alto Meridione: Il caso del napoletano". The Italianist 28: 281-301. http://dx.doi.org/10.1179/026143408x363587

Ledgeway, Adam. 2009. Grammatica diacronica del napoletano. Tübingen: Max Niemeyer Verlag.

Lenz, Alexandra N. 2007a. "Zur Grammatikalisierung von geben im Deutschen und Letzebuergeschen". Zeitschrift für Germanistische Linguistik 35: 52-82. http://dx.doi.org/10.1515/zgl.2007.004

Lenz, Alexandra N. 2007b. "About the grammaticalization of geben 'to give'”. In S. Elspaß, N. Langer, J. Scharloth and W. Vandenbussche (eds.), Germanic Language Histories 'from below' (1700-2000), 163-178. Berlin/New York: De Gruyter. http://dx.doi.org/10.1515/9783110925463.163

Leonetti, Manuel. 2004. "Specificity and object marking: The case of Spanish $a$ ". In K. von Heusinger and G. Kaiser (eds.), Proceedings of the Workshop "Semantic and Syntactic Aspects of Specificity in Romance Languages", 
67-101. Konstanz: Universität Konstanz, Konstanzer Arbeitspapiere des Fachbereichs Sprachwissenschaft (No. 113).

Leonetti, Manuel. 2008a. "Definiteness Effects and the role of the coda in existential constructions". In H. H. Müller and A. Klinge (eds.), Essays on Nominal Determination, 131-162. Amsterdam: John Benjamins. http://dx.doi.org/10.1075/slcs.99.09leo

Leonetti, Manuel. 2008b. "Specificity in clitic doubling and in differential object marking”. Probus 20: 35-69. http://dx.doi.org/10.1515/probus.2008.002

Longa, Víctor, Guillermo Lorenzo and Gemma Rigau. 1998. "Subject clitics and clitic recycling: locative sentences in some Iberian Romance languages". Journal of Linguistics 34: 125-164. http://dx.doi.org/10.1017/s0022226797006853

Lurà, Franco. 1987. Il dialetto del Mendrisiotto: Descrizione sincronica e confronto coll'italiano. Mendrisio and Chiasso: Unione di Banche Svizzere.

Lyons, John. 1967. "A note on possessive, existential and locative sentences". Foundations of Language 3: 390-396.

Maiden, Martin. 1995. A Linguistic History of Italian. London: Longman.

Manzini, Maria Rita and Leonardo Savoia. 2005. I dialetti italiani e romanci. Morfosintassi generativa. Alessandria: Edizioni Dell'Orso.

Marten, Lutz. 2013. "Structure and interpretation in Swahili existential constructions". Italian Journal of Linguistics 25: 45-73.

McNally, Louise. 1992. An Interpretation for the English Existential Construction. Ph.D. thesis, University of California, Santa Cruz. Published by Garland Press, New York, 1997.

McNally, Louise. 2011. "Existential sentences". In Claudia Maienborn, K. von Heusinger and P. Portner (eds.), Semantics: An International Handbook of Natural Language Meaning, Vol. 2, 1829-1848. Berlin, Mouton de Gruyter. http://dx.doi.org/10.1515/9783110255072.1829

Milsark, Gary. 1974. Existential Sentences in English. Ph.D. thesis, MIT. Published by Garland Press, New York, 1979.

Moro, Andrea. 1997. The Raising of Predicates: Predicative Noun Phrases and the Theory of Clause Structure. Cambridge: Cambridge University Press. http://dx.doi.org/10.1017/cbo9780511519956

Moro, Andrea. 1998. "Esserci et averci: Les clitiques sujets et une analyse en «petite proposition» pour avere". In A. Rouveret (ed.), ETRE et AVOIR syntaxe, semantique, typologie, 155-170. Saint Denis: Presses Universitaires de Vincennes.

Nocentini, Alberto. 1999. "Topical Constraints on Verbal Agreement of Spoken Italian (Tuscan Variety)". Italian Journal of Linguistics 11 (2): 315-339.

Parry, Mair. 2010. "Non-canonical subjects in the early Italian vernaculars". Archivio Glottologico Italiano 95: 190-226.

Partee, Barbara H. and Vladimir Borschev. 2002. "Genitive of negation and scope of negation in Russian existential sentences". In J. Toman (ed.), Formal Approaches to Slavic Linguistics: The Ann Arbor Meeting 2001 (FASL 10), 181-200. Ann Arbor: Michigan Slavic Publication.

Partee, Barbara H. and Vladimir Borschev. 2007. "Existential sentences, BE, and the genitive of negation in Russian". In I. Comorovski and K. von Heusinger (eds.), Existence: Semantics and Syntax, 147-190. Dordrecht, Springer. 
http://dx.doi.org/10.1007/978-1-4020-6197-4_6

Pinto, Manuela. 1997. Licensing and Interpretation of Inverted Subjects in Italian. Utrecht: UiL OTS Dissertation Series.

Poletto, Cecilia. 2000. The Higher Functional Field: Evidence from Northern Italian Dialects. Oxford/New York: Oxford University Press.

Posner, Rebecca. 1996. The Romance Languages. Cambridge: Cambridge University Press.

Rando, Emily and Donna J. Napoli. 1978. "Definites in there-sentences". Language 54: 300-313.

http://dx.doi.org/10.2307/412949

Remberger, Eva-Maria. 2009. "Null Subjects, Expletives and Locatives in Sardinian". In G. Kaiser and E-M. Remberger (eds.), Proceedings of the workshop "Null subjects, expletives and locatives in Romance", 231-261. Konstanz: Universität Konstanz, Konstanzer Arbeitspapiere des Fachbereichs Sprachwissenschaft (No. 123).

Rigau, Gemma. 1994. "Catalan presentational sentences and the properties of Agr nodes". In G. Cinque, J. Koster, J-Y. Pollock, L. Rizzi and R. Zanuttini (eds.), Paths towards Universal Grammar: Studies in Honor of Richard S. Kayne, 343-359. Washington D.C.: Georgetown University Press.

Rigau, Gemma. 1997. "Locative sentences and related constructions in Catalan: ésser / haver alternation". In A. Mendikoetxea and M. Uribe-Etxebarría (eds.), Theoretical Issues at the Morphology-Syntax Interface, 395-421. Bilbao: Universidad del País Vasco.

Rodríguez Mondoñedo, Miguel. 2006. "Spanish existentials and other accusative constructions". In C. Boeckx (ed.), Minimalist Essays, 326-394. Amsterdam: John Benjamins. http://dx.doi.org/10.1075/la.91.20rod

Rohlfs, Gerhard. 1969. Grammatica storica della lingua italiana e dei suoi dialetti: Sintassi e formazione delle parole. Turin: Einaudi.

Rohlfs, Gerhard. 1977. Grammatica storica dei dialetti italogreci (Calabria, Salenti). Nuova edizione interamente rielaborata ed aggiornata. Munich: Beck.

Rossi Taibbi, Giuseppe and Girolamo Caracausi. 1959. Testi neogreci di Calabria. Palermo: Istituto Siciliano di Studi Bizantini e Neogreci.

Saccon, Graziella. 1993. Post-verbal Subjects: A Study Based on Italian and Its Dialects. Ph.D. thesis, Harvard University.

Sheehan, Michelle. 2006. The EPP and Null Subjects in Romance. Ph.D. thesis, University of Newcastle.

Sheehan, Michelle. 2010. "'Free' inversion in Romance and the Null Subject Parameter". In T. Biberauer, A. Holmberg, I. Roberts and M. Sheehan, Parametric Variation: Null Subjects in Minimalist Theory, 231-262. Cambridge: Cambridge University Press. http://dx.doi.org/10.1017/cbo9780511770784.007

Sorrenti, Elisa. in prep. Existential Sentences and Definiteness Effects in Southern Calabrese. Ph.D. thesis, University of Hamburg.

Suñer, Margarita. 1982. Syntax and Semantics of Spanish Presentational Sentence Types. Washington D. C.: Georgetown University Press.

Szabolcsi, Anna. 1983. "The possessor that ran away from home". The Linguistic Review 3: 89-102. http://dx.doi.org/10.1515/tlir.1983.3.1.89 
Torrego, Esther. 1998. The Dependencies of Objects. Cambridge, MA: MIT Press.

Torrego, Esther. 1999. "El complemento directo preposicional". In Ignacio Bosque and Violeta Demonte (eds.), Gramática descriptiva de la lengua española Vol. 2: Las construcciones sintácticas fundamentales. Relationes temporales, aspectuales y modales, 1779-1805. Madrid: Espasa Calpe.

Tortora, Christina. 1997. The Syntax and Semantics of the Weak Locative. Ph.D. thesis, University of Delaware.

Tortora, Christina. 2001. "Evidence for a null locative in Italian". In Guglielmo Cinque and Giampaolo Salvi (eds.), Current Studies in Italian Syntax: Essays Offered to Lorenzo Renzi, 313-326. Amsterdam, Elsevier.

Tsunoda, Tasaku. 1985. "Remarks on transitivity". Journal of Linguistics 21: 386396. http://dx.doi.org/10.1017/s0022226700010318

Uriagereka, Juan. 1998. "From being to having: Questions about ontology from a Kayne/Szabolcsi syntax". In A. Schwegler, B. Tranel and M. UribeEtxebarria (eds.), Romance Linguistics: Theoretical Perspectives. Selected papers from the 27th Linguistic Symposium on Romance Languages (LSRL XXVII), Irvine, 20-22 February, 1997, 283-306. Amsterdam: John Benjamins. http://dx.doi.org/10.1075/cilt.160.21uri

Villalba, Xavier. 2013. "Eventive existentials in Catalan and the Topic-Focus articulation". Italian Journal of Linguistics 25: 147-173.

von Heusinger, Klaus and Georg Kaiser. 2007. "Differential object marking and the lexical semantics of verbs in Spanish". In G. Kaiser and M. Leonetti (eds.), Proceedings of the Workshop "Definiteness, Specificity and Animacy in Ibero-Romance languages", 85-110. Konstanz: Universität Konstanz, Konstanzer Arbeitspapiere des Fachbereichs Sprachwissenschaft (No. 122).

Wagner, Max Leopold. 1960. Dizionario etimologico sardo (vol. 1). Heidelberg: Winter.

Waltereit, Richard and Ulrich Detges. 2008. "Syntactic change from within and from without syntax: A usage-based analysis". In R. Waltereit and U. Detges (eds.), The Paradox of Grammatical Change: Perspectives from Romance, 13-30. Amsterdam: John Benjamins. http://dx.doi.org/10.1075/cilt.293.02wal

Ward, Gregory and Betty, Birner. 1995. "Definiteness and the English existential”. Language 71: 722-742. http://dx.doi.org/10.2307/415742 